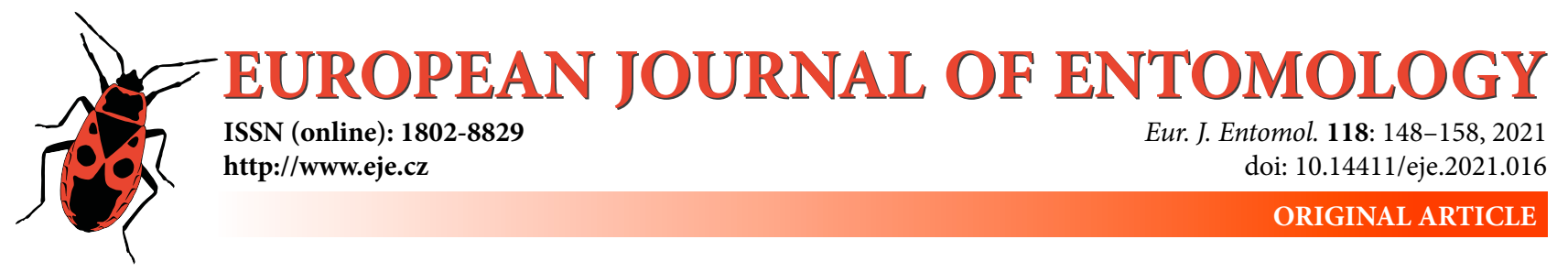

\title{
Mortality factors acting on field populations of Bemisia tabaci (Hemiptera: Aleyrodidae) SSA1 on cassava in Uganda
}

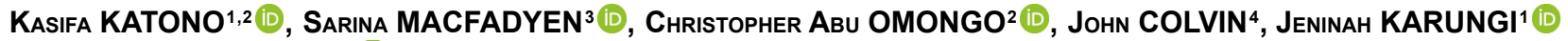 \\ and Michael HILARY OTIM ${ }^{2}$ (D)
}

\author{
${ }^{1}$ Makerere University, P.O. Box 7062, Kampala, Uganda; e-mails: kasifakats@yahoo.com, jtumutegyereize@gmail.com \\ ${ }^{2}$ National Crops Resources Research Institute, P.O. Box 7084, Kampala, Uganda; e-mails: chrisomongo@yahoo.com, \\ motim9405@gmail.com \\ ${ }^{3}$ CSIRO, Clunies Ross St., Acton, ACT, 2601, Australia; e-mail: sarina.macfadyen@csiro.au \\ ${ }^{4}$ Natural Resources Institute, University of Greenwich, Chatham Maritime, Kent, ME4 4TB, UK; e-mail: j.colvin@greenwich.ac.uk
}

Key words. Hemiptera, Aleyrodidae, Bemisia tabaci, life table, marginal mortality, key factor, disappearance, parasitism

\begin{abstract}
Natural death is a key determinant of a species population dynamics. Thus, a clear understanding of natural mortality factors aids the development of appropriate management strategies for insect pests. Cohort-based life tables were constructed to determine the sources and rates of mortality of field populations of the pest, Bemisia tabaci Sub-Saharan Africa 1 (SSA1) on cassava in Uganda. Monthly cohorts (10 in total) were established separately for eggs and nymphs on two cassava genotypes with known levels of resistance to $B$. tabaci infestation (Alado alado and NAROCASS 1). Mortality was recorded using daily observations for the eggs and the different nymphal instars. The recorded mortality sources were disappearance (total removal of egg or nymph from the leaf), predation, parasitism (nymphs only), unknown death and inviability (eggs only). Median marginal mortality rate was highest for disappearance $(0.355)$ followed by parasitism $(0.058)$. The highest level of mortality occurred during the third nymph stage ( $55 \%$ on Alado alado) and only $12 \%$ of nymphs reached the adult stage. Irreplaceable mortality (IC) was highest for disappearance followed by third instar parasitism. Key-factor analysis revealed a close resemblance of the curve for disappearance to that of total mortality coupled with the highest regression slopes: 0.896 for eggs and 0.725 for nymphs on NAROCASS 1. From these results, we conclude that disappearance and parasitism are the major mortality factors controlling $B$. tabaci SSA1 populations. Therefore, the development of interventions that focus on enhancing the levels of disappearance and third instar parasitism may lead to population-level reductions in $B$. tabaci SSA1. Further studies need to be conducted to understand the factors that contribute to the high mortality associated with disappearance.
\end{abstract}

\section{INTRODUCTION}

Several abiotic and biotic mortality forces including predators, parasitoids, pathogens, and weather have been reported to act on Bemisia tabaci Gennadius (Hemiptera: Aleyrodidae) pest complex populations (Naranjo, 2001; Naranjo \& Ellsworth, 2005). The timing and relative importance of these mortality factors is a key determinant of the population dynamics (Naranjo \& Ellsworth, 2005), especially for insects that cause economic damage to crop plants (Baskauf, 2003). There are currently over 40 cryptic species in the Bemisia tabaci complex (Hu et al., 2017; Jiu et al., 2017; Dinsdale et al., 2010) and they are all polyphagous phloem-feeders (Polston et al., 2014). Their populations have reportedly increased in abundance throughout the cassava-growing regions of East and Central Africa over the past two decades (Colvin et al., 2004; Legg et al., 2014a; Ally et al., 2019). The current outbreaks of B. tabaci populations heighten its importance as a direct pest of cassava and also intensify its role as a vector of two damaging viral diseases of cassava: Cassava Mosaic Disease (CMD) and Cassava Brown Streak Disease (CBSD) (Legg et al., 2014b; Maruthi et al., 2017), thus undermining food security and livelihood benefits of cassava production. In Sub-Saharan Africa, cassava is considered a staple crop that is highly resilient to climate change (Nweke et al., 2002; Jarvis et al., 2012; Maruthi et al., 2017).

Though many mortality factors are known to impact $B$. tabaci field populations (Gerling et al., 2001; Naranjo \& Ellsworth, 2005), there is limited information on the rates of mortality associated with specific causes of death, especially in light of the different $B$. tabaci species currently described. Age-specific life tables for insects under field conditions provide critical information for a given cohort of individuals thus helps to identify mortality factors responsible for population regulation (Choudhury et al., 2013). Life tables have previously been used to study the 
population dynamics of $B$. tabaci on cotton (Naranjo \& Ellsworth, 2005). Asiimwe et al. (2007) using cohort-based life tables determined that fourth instar parasitism and disappearance were the key nymph and egg mortality factors for B. tabaci on cassava in Uganda. However, CMD was the key production constraint for cassava in Uganda at that time, in 2003. With the current CBSD epidemic, most of the CMD resistant cassava genotypes have been replaced with CBSD tolerant genotypes (Alicai et al., 2007; Kawuki et al., 2016), which unfortunately support very high populations of B. tabaci (Otim et al., 2006; Omongo et al., 2012). Also, the B. tabaci species complex was unknown at the time of the Asiimwe et al. (2007) study. Currently, cassava in Uganda is largely infested by B. tabaci SubSaharan Africa 1 (SSA1) species (Mugerwa et al., 2012; Legg et al., 2014a; Kalyebi et al., 2018; Ally et al., 2019).

This study sought to develop comprehensive life tables for B. tabaci SSA1 on cassava and estimate the impact of specific mortality factors affecting each immature growth stage of $B$. tabaci SSA1 on cassava. We used a controlled field experiment to standardize the number of eggs and nymphs observed in each cohort to more accurately contrast the effect on B. tabaci mortality of two cassava genotypes that reportedly have different levels of resistance to whitefly infestation.

\section{MATERIALS AND METHODS}

\section{Study site, genotypes used, and experimental layout}

This study was conducted in Wakiso district $\left(0.518991^{\circ} \mathrm{N}\right.$, $32.636165^{\circ} \mathrm{E}$ ) in Uganda in 2016 and 2017 using two cassava genotypes; NAROCASS 1 and Alado alado as treatments. NAROCASS 1 is an improved genotype that is susceptible to $B$. tabaci infestation, whereas Alado Alado is a local genotype that is tolerant to $B$. tabaci infestation, thus support high and low $B$. tabaci populations respectively (Omongo et al., 2012; Kawuki et al., 2016; Katono et al., unpubl.). The experiment was laid out in a randomized complete block design with three replicates. The plots measured $9 \mathrm{~m}$ by $9 \mathrm{~m}$ with plants spaced at $1 \mathrm{~m}$ by $1 \mathrm{~m}$. Two-meter alleys, without any plants, were left between blocks. Weeds were removed manually by hoeing monthly for the first five months.

\section{Cohort establishment}

Monthly, egg and nymph cohorts were established on 10 randomly selected plants per plot. The cohorts, selected from naturally occurring populations, were established between 08:00 and
11:00 h, on different plants. Five cohorts were established at 3-7 months after planting (MAP) in both 2016 and 2017. Hence, we observed mortality on 10 cohorts in total on each cassava genotype.

\section{Egg cohorts}

Ten freshly laid eggs were identified on the underside of the top-most expanded plant leaf using a $10 \times$ hand lens on each genotype per replicate plot. For each replicate plot, 10 plants were selected thus 100 eggs were marked per replicate plot per cassava genotype. A total of 300 eggs were marked for each cassava genotype per cohort. All other eggs on the leaf were removed by gently brushing them off the leaf using the edge of soft tissue paper. The eggs were marked by drawing a small circle around each egg using a nontoxic pen. A red tag was then tied around the petiole of the leaf bearing the marked eggs so they could be easily found again.

\section{Nymph cohorts}

For each replicate plot, 10 plants were selected, and on each plant, 30 first-instar nymphs were identified and marked on a single leaf. Thus a total of 300 nymphs per replicate plot per cassava genotype were marked. Each nymph cohort consisted of 900 nymphs per cassava genotype. The nymphs were marked using the same procedure described for eggs. A green tag was used to mark the leaves having the marked nymphs. Marked nymphs were checked after one hour to ascertain that they had settled and any nymph that had crawled out of the circle was replaced by marking another one.

\section{Determination of mortality factors and recording of egg eclosion and nymph development}

Each marked egg was observed daily using a $10 \times$ hand lens for 15 days, which is more than the 11-day egg hatching period on cassava (Legg, 1995). Marked nymphs were observed for 30 days, a period sufficient for both $B$. tabaci and parasitoid adult emergence (Asiimwe et al., 2007). Each day, the stage and state of each egg and nymph were recorded and categorized as healthy or dead. Death was then characterized as disappearance, predation, parasitism, inviability, and unknown death (Table 1; Naranjo \& Ellsworth, 2005, 2017; Asiimwe et al., 2007; Banjo, 2010). Mortality in the crawler stage was missed and thus not accounted for in this study. However, Naranjo (2007) and Karut \& Naranjo (2009) indicated that B. tabaci crawler mortality on cotton was negligible.

\section{Data analysis}

\section{Multiple decrement life table}

The raw data were summarized to generate a table showing the total number of insects at the beginning of each stage $\left(\mathrm{N}_{x}\right)$ and the

Table 1. Classification and description of mortality components* acting on $B$. tabaci SSA1 egg and nymph populations on cassava in the field.

\begin{tabular}{|c|c|}
\hline Cause of death & Description \\
\hline Disappearance & $\begin{array}{l}\text { Egg or nymph goes missing due to total removal by a chewing predator, or dislodgement from the leaf } \\
\text { due to wind or rain. }\end{array}$ \\
\hline Predation & Sucking predators evacuate the contents of the prey and leave behind an empty egg chorion or nymph cuticle. \\
\hline Parasitism** & $\begin{array}{l}\text { The paired yellowish mycetomes are displaced by the developing parasitoid larva, and in the case of parasitism } \\
\text { by Encarsia sophia, the nymph turns black. }\end{array}$ \\
\hline Inviability & Eggs fail to hatch by the fourteenth day and are dark tan in colour. \\
\hline Unknown death & $\begin{array}{l}\text { A death that is attributed to any cause excluding those described above. } \\
\text { There is evidence of the carcass on the leaf (i.e., the individual has not disappeared). }\end{array}$ \\
\hline
\end{tabular}


number of deaths from all causes $\left(D_{x}\right)$ at a given stage of growth (Table S1). The number of deaths from the different causes was denoted as $\mathrm{D}_{i x}$. This information was then used to estimate the probability of death from all causes $\left(\mathrm{aq}_{x}\right.$ : Table $\left.\mathrm{S} 2\right)$ at a given stage of growth according to Carey, 1989. The $\mathrm{aq}_{x}$ values were then used to compute the survival ( $\mathrm{al}_{x}$ : Table $\mathrm{S} 3$ ) of the immature B. tabaci populations subjected to all causes of death in a given stage to construct the multiple decrement life table following the methods of Carey (1989).

\section{Determination of mortality rates}

Age-specific marginal mortality rates (MMR) for each factor were estimated based on apparent (observed) mortality rates (AMR) according to the methods of Buonaccorsi \& Elkinton (1990) and Naranjo \& Ellsworth (2005). Marginal mortality rate estimates the level of death arising from a single factor assuming that it was the only one operating at the time (Naranjo \& Ellsworth, 2005). However, a mortality factor may be masked by another factor since they operate concurrently with no clear order of events (Naranjo \& Ellsworth, 2005; Asiimwe et al., 2007). Disappearance is the only factor for which the AMR is equal to the MMR because it cannot be concealed by any other factor (Naranjo \& Ellsworth, 2005; Asiimwe et al., 2007). The general equation for determining MMR was derived from Naranjo \& Ellsworth (2005) as below:

$$
M_{A x}=\frac{d_{A x}}{1-d_{B x}}
$$

where $M_{A x}$ is the MMR due to factor A in stage $\mathrm{x}, d_{A x}$ is the AMR due to factor A in stage $\mathrm{x}$ and $d_{B x}$ is the sum of apparent mortalities from all other relevant contemporaneous factors. MMR were calculated separately for each development stage and for each mortality factor. Due to the concurrent nature of the mortality from other factors that act on the immature stages of $B$. tabaci, the AMRs needed to estimate MMR for each mortality factor with each growth stage is given in Table 2 (Naranjo \& Ellsworth, 2005; Asiimwe et al., 2007).

\section{Estimation of irreplaceable mortality $\left(I_{c}\right)$}

Irreplaceable mortality is that portion of total cohort mortality that would not occur if a given mortality factor was eliminated (Carey, 1989; Naranjo \& Ellsworth, 2005). Irreplaceable mortality $\left(I_{C}\right.$ was calculated for each mortality factor within each growth stage according to Carey (1989) and Naranjo \& Ellsworth (2005) using the equation below:

$$
I_{C}=\left(1-\prod_{1}^{j}\left[1-M_{i}\right]\right)-\left(1-\prod_{1}^{j-1}\left[1-M_{i}\right]\right)
$$

where $M_{i}$ is the marginal mortality rate for factor $i$, and $j$ is the total number of all mortality factors acting in a given stage. The first product includes all mortality factors, while the second product includes all mortality factors except the factor of interest.

\section{Analysis of variance}

All data on MMR, $I c$, and $k$-values were tested for normality, and where skewness occurred, data were subjected to the
Box-Cox procedure (Venables \& Ripley, 2002) to determine the most appropriate transformation based on the lambda value. The data for eggs and nymphs were then subjected to a nested model ANOVA (Bates et al., 2015) to check the strength of the variability due to cassava genotype, cause of death and stage of growth on marginal mortality rate, irreplaceable mortality and mean levels of death $(k$ value). Cause of death and stage of growth were nested within genotype. Data on eggs, early nymphs (first and second instar stages), and late nymphs (third and fourth instar) were separated because different mortality factors acted in the different stages.

\section{Key-factor analysis}

The graphical method of (Varley \& Gradwell, 1960) which compares patterns of total mortality (total $K=\Sigma k$ ) for the cohort to that of individual k-values $[k=-\ln (1-M)]$ for each mortality factor was used to determine the relative contribution of individual causes of death to total mortality. The factor whose graph most closely resembles that of total $\mathrm{K}$ is the key factor (Naranjo \& Ellsworth, 2017). To further quantify the key factors, individual k-values were regressed against total $\mathrm{K}$, and the factor whose individual $k$-values had the largest slope was denoted as the key factor (Podoler \& Rogers, 1975).

\section{Relationship between environmental parameters and the different mortality factors}

Air temperature and relative humidity $(\mathrm{RH})$ were recorded using a data logger placed at the trial site. Sunshine hours, wind speed, and rainfall data were accessed from the weather station at the National Crops Resources Research Institute. The daily readings recorded at 15:00 $\mathrm{h}$ for rainfall, air temperature, $\mathrm{RH}$, sunshine hours, and wind speed were used to calculate the total monthly rainfall, average monthly air temperature, $\mathrm{RH}$, sunshine hours, and wind speed values (i.e. a month was from the date of cohort establishment to the date the last nymph dies or emerges into an adult, and the date the last egg hatches into a first-instar nymph or $15^{\text {th }}$ day after cohort establishment).

Correlation analysis was then performed to determine the strength and the direction of the relationship between weather parameters with $B$. tabaci egg and nymph mortality rates (Revelle, 2017).

\section{RESULTS}

\section{Sources and levels of mortality}

From the ANOVA result, the variation in MMR, Ic and $k$-value was due to cause of death nested within genotype (Table 3). There was considerable variation in MMRs for each cause of death when pooled over all immature stages; the highest median rates of death were associated with disappearance in both genotypes in all cohorts; median MMR was 0.355 in Alado alado (Fig. 1A). Parasitism caused the second highest MMR; 0.084 in NAROCASS 1 and 0.058 in Alado alado (Fig. 1A). Also, when pooled over all mortality factors, sizeable variation in MMR was observed in each development stage and the highest median rate of

Table 2. Matrix for determining marginal mortality rates for populations of Bemisia tabaci SSA1 from apparent rates of relevant competing

\begin{tabular}{|c|c|c|c|}
\hline Marginal mortality rate of interest $\left(M_{A}\right)$ & Apparent mortality rate $\left(d_{A}\right)$ & Other apparent mortality rate $\left(d_{B}\right)$ & Growth stage \\
\hline Inviability & Inviability & Predation + Disappearance & Egg \\
\hline Predation & Predation & Disappearance & Egg and all nymph stages \\
\hline Disappearance & Disappearance & No competing factor & Egg and all nymph stages \\
\hline Parasitism & Parasitism & Predation + Disappearance & Third and fourth instar nymphs \\
\hline Unknown death & Unknown death & Predation + Disappearance & All nymph stages \\
\hline
\end{tabular}
contemporaneous factors. 

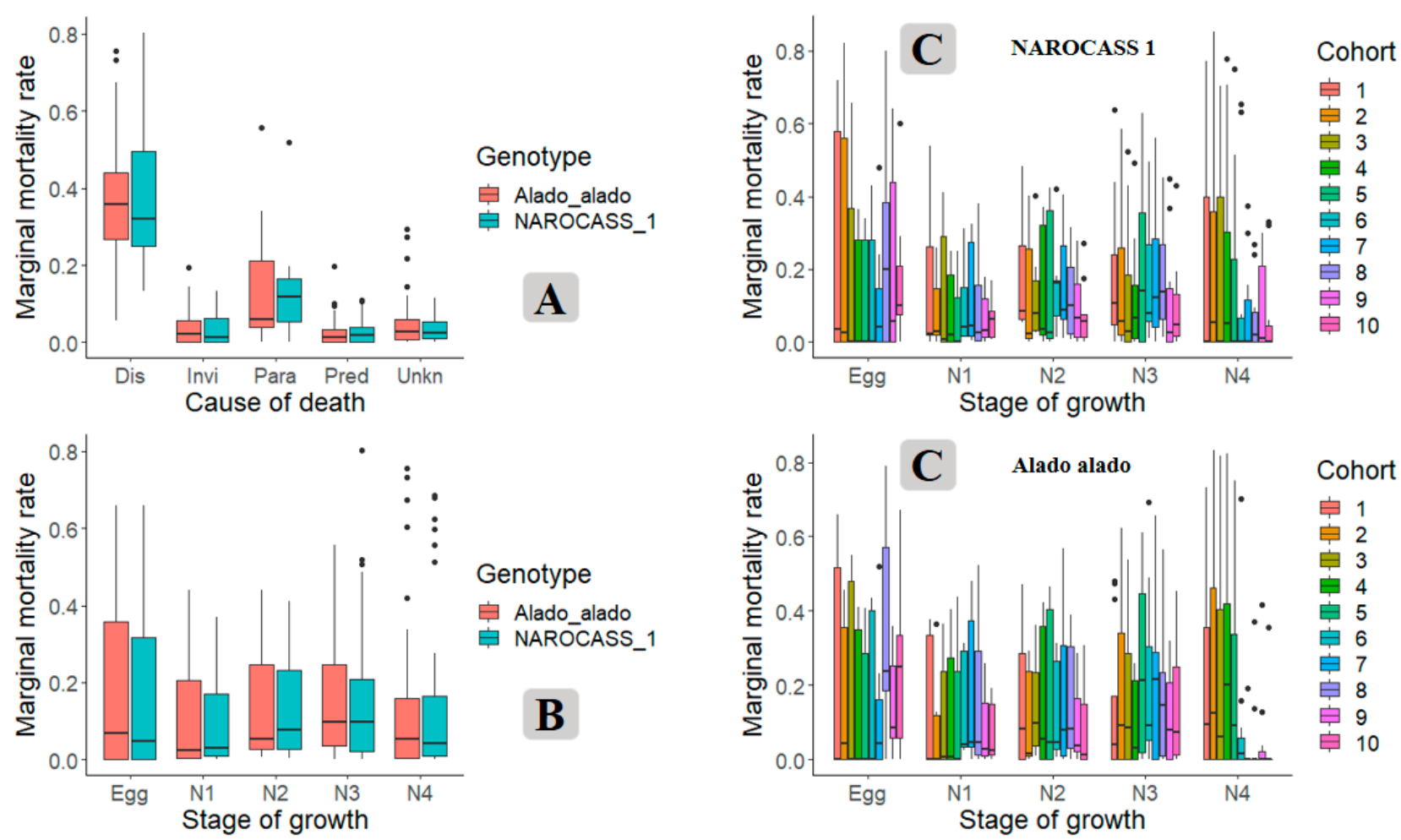

Fig. 1. Box plots of marginal mortality rates (MMR) for Bemisia tabaci SSA1 on two cassava genotypes by cause of death pooled over all immature growth stages (A) and during each stage growth pooled over all causes of death (B) for 10 cohorts and during each stage growth pooled over all causes of death (C) in 10 cohorts on two cassava genotypes. N1 $-1^{\text {st }}, N 2-2^{\text {nd }}, N 3-3^{\text {rd }}, N 4-4^{\text {th }}$ instar nymph; Dis - disappearance, Invi - inviability, Pred - predation, Para - parasitism and Unkn - unknown death.

mortality was associated with the third instar stage for both genotypes; 0.092 in Alado alado and 0.073 in NAROCASS 1 (Fig. 1B). The highest cohort mortality was observed in the $8^{\text {th }}$ and $10^{\text {th }}$ cohorts in the egg stage for NAROCASS 1 (median MMR was 0.2) and Alado alado (median MMR of 0.25 ) respectively (Fig. $1 \mathrm{C}$ ).

In all growth stages for both genotypes, the highest mortality was associated with disappearance followed by parasitism in the third and fourth nymph stages (Fig. 2A). Similarly, when all the growth stages were pooled together, disappearance was associated with the highest levels of death across all the 10 cohorts in both genotypes (Fig. 2B). Across all the 10 cohorts in both genotypes, the third instar stage displayed consistently high levels of death compared with the fourth instar stage where mortality was highest from cohort one (1) to six (6) and minimum from cohort seven (7) to 10 (Fig. 2C).

At all growth stages, disappearance has the highest irreplaceable mortality followed by parasitism in the $3^{\text {rd }}$ instar stage in both genotypes (Fig. 3).

\section{Relationship and dynamics of $B$. tabaci adult and nymph occurrence with environmental factors}

Correlation analysis was focused on the strength and direction of the relationship between average monthly air temperature, relative humidity $(\mathrm{RH})$, sunshine hours and wind speed, and total monthly rainfall with monthly mean levels of mortality ( $\mathrm{k}$ values) of the different mortality factors per cohort (cohorts 1 to 5; 2016 and 6 to 10; 2017). In both years, the effects of the different weather parameters on the various mortality factors were inconsistent, e.g. the effect of rainfall on nymph disappearance in 2016 was positive $(r=0.65)$ while a negative relationship $(r=-0.56)$ was observed in 2017 (Table 4).

For nymph populations, strong positive and negative relationships of average monthly air temperature, $\mathrm{RH}$, and total rainfall with all nymph mortality factors in 2016; $r=-0.87,0.75,0.51$ for the effect of air temperature on disappearance, parasitism, and predation, resp. (Table 4). Sunshine hours had strong effects on predation $(r=0.54)$ and unknown death $(r=0.77)$ (Table 4). In 2017, RH

Table 3. Variance associated with genotype, cause of death, and stage of growth on mortality of immature stages of $B$. tabaci SSA1 on cassava in Uganda.

\begin{tabular}{|c|c|c|c|c|c|c|c|c|c|}
\hline \multirow{2}{*}{ Group } & \multicolumn{3}{|c|}{ Early nymphal stages } & \multicolumn{3}{|c|}{ Late nymphal stages } & \multicolumn{3}{|c|}{ Egg stage } \\
\hline & MMR & Ic & k-value & MMR & Ic & k-value & MMR & IC & k-value \\
\hline Genotype & 0.0000 & 0.0000 & 0.0000 & 0.0000 & 0.0000 & 0.0000 & 0.0000 & 0.0000 & 0.0000 \\
\hline Cause of death: Genotype & 0.0179 & 0.0168 & 0.0277 & 0.0453 & 0.0401 & 0.0994 & 0.0453 & 0.0401 & 0.0994 \\
\hline Growth stage: Genotype & 0.0004 & 0.0001 & 0.0006 & 0.0000 & 0.0000 & 0.0000 & 0.0000 & 0.0000 & 0.0000 \\
\hline Residual & 0.0046 & 0.0037 & 0.0090 & 0.0135 & 0.0085 & 0.0484 & 0.0135 & 0.0085 & 0.0484 \\
\hline
\end{tabular}




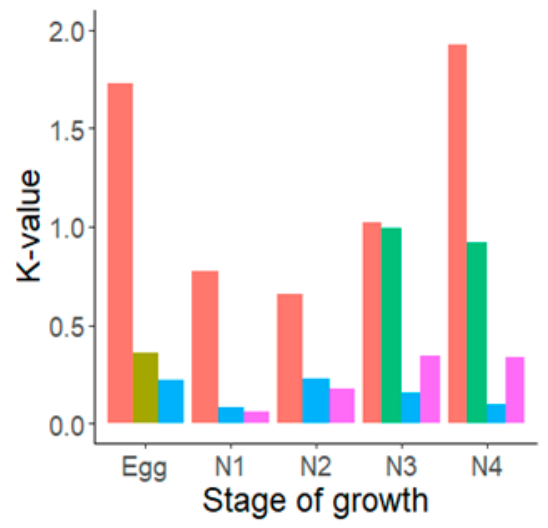

Cause_of_death

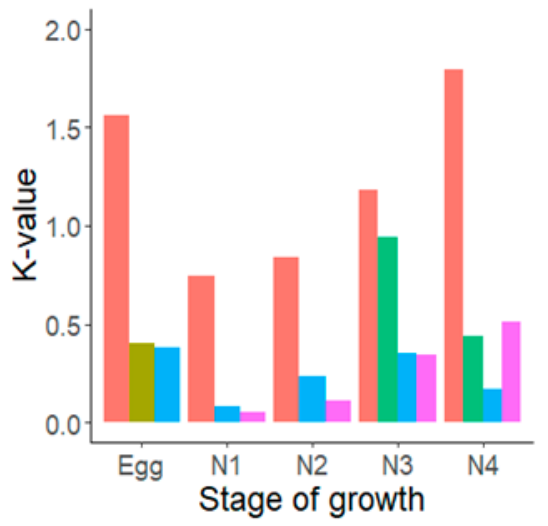

Cause_of_death

Dis

Invi

Para

Pred

Unkn

A

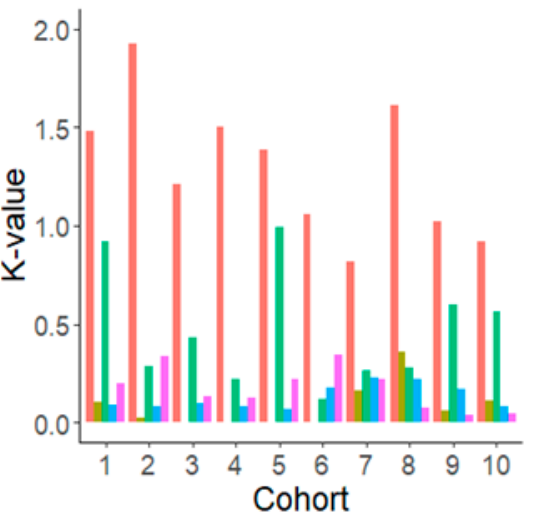

Cause_of_death

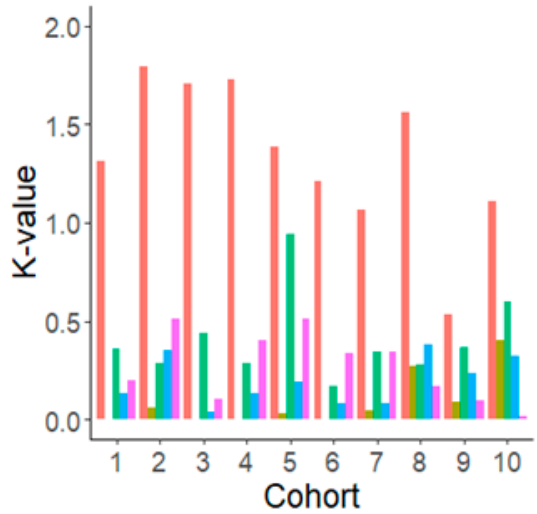

Dis

Invi

Para

Pred

Unkn

A

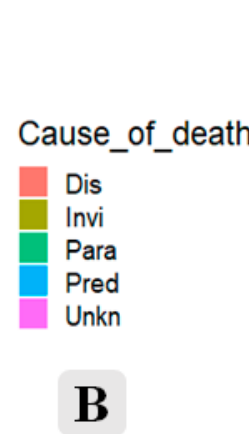

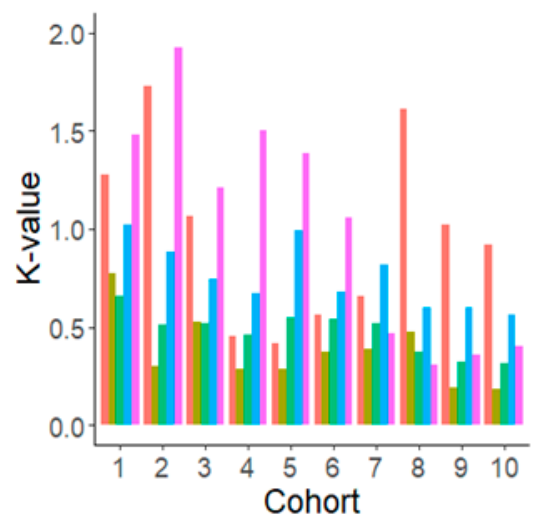

NAROCASS 1
Stage of growth

Egg
N1
N2
N3
N4
C

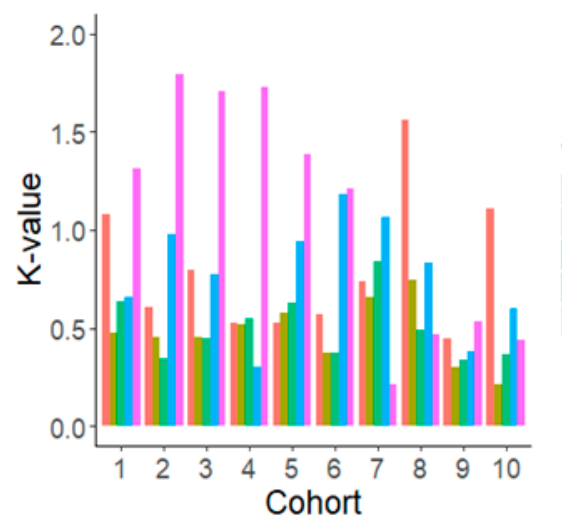

Stage_of_growth

Egg

N1

N2

N3

N4

C

Fig. 2. Mean levels of mortality expressed as $\mathrm{K}$ values within each stage of growth of Bemisia tabaci SSA1 species across all cohorts (A), for each cohort pooled over all stages of growth (B) for the different mortality factors, and for each cohort for the five stages of growth pooled over all mortality factors (C) on two cassava genotypes. N1 $-1^{\text {st }}, \mathrm{N} 2-2^{\text {nd }}, \mathrm{N} 3-3^{\text {rd }}, \mathrm{N} 4-4^{\text {th }}$ instar nymph; Dis - disappearance, Invi - inviability, Pred - predation, Para - parasitism and Unkn - unknown death.
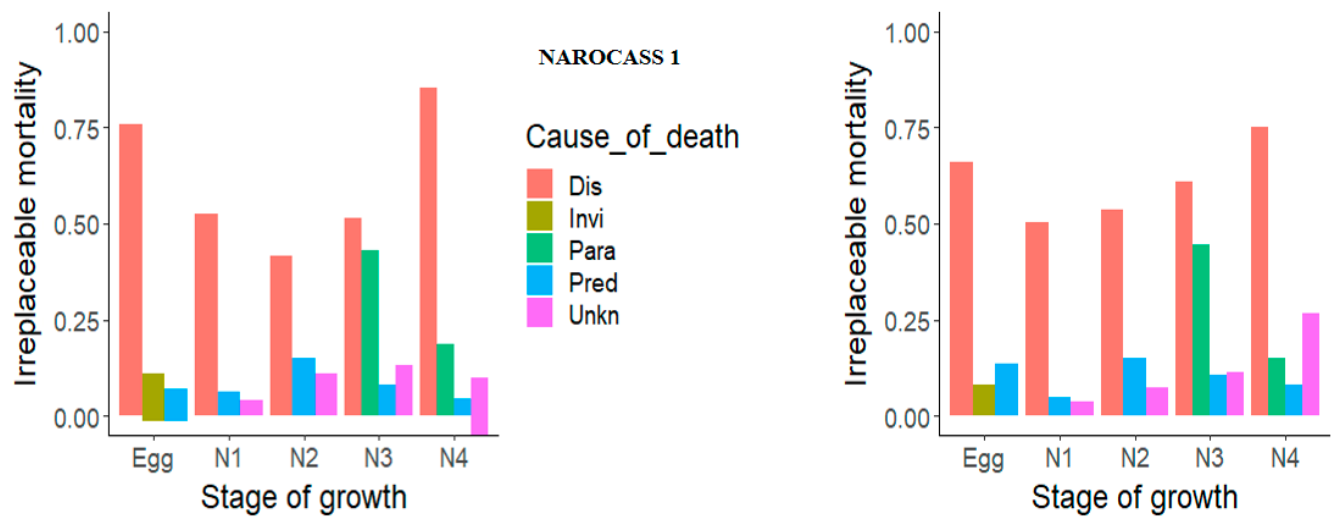

Alado alado

Cause_of_death

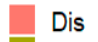

Invi

Para

Pred

Unkn

Fig. 3. Irreplaceable mortality within each stage of growth of Bemisia tabaci SSA1 for the different mortality factors on two cassava genotypes across all cohorts. N1 $-1^{\text {st }}, \mathrm{N} 2-2^{\text {nd }}, \mathrm{N} 3-3^{\text {rd }}, \mathrm{N} 4-4^{\text {th }}$ instar nymph; Dis - disappearance, Invi - inviability, Pred - predation, Para - parasitism and Unkn - unknown death. 


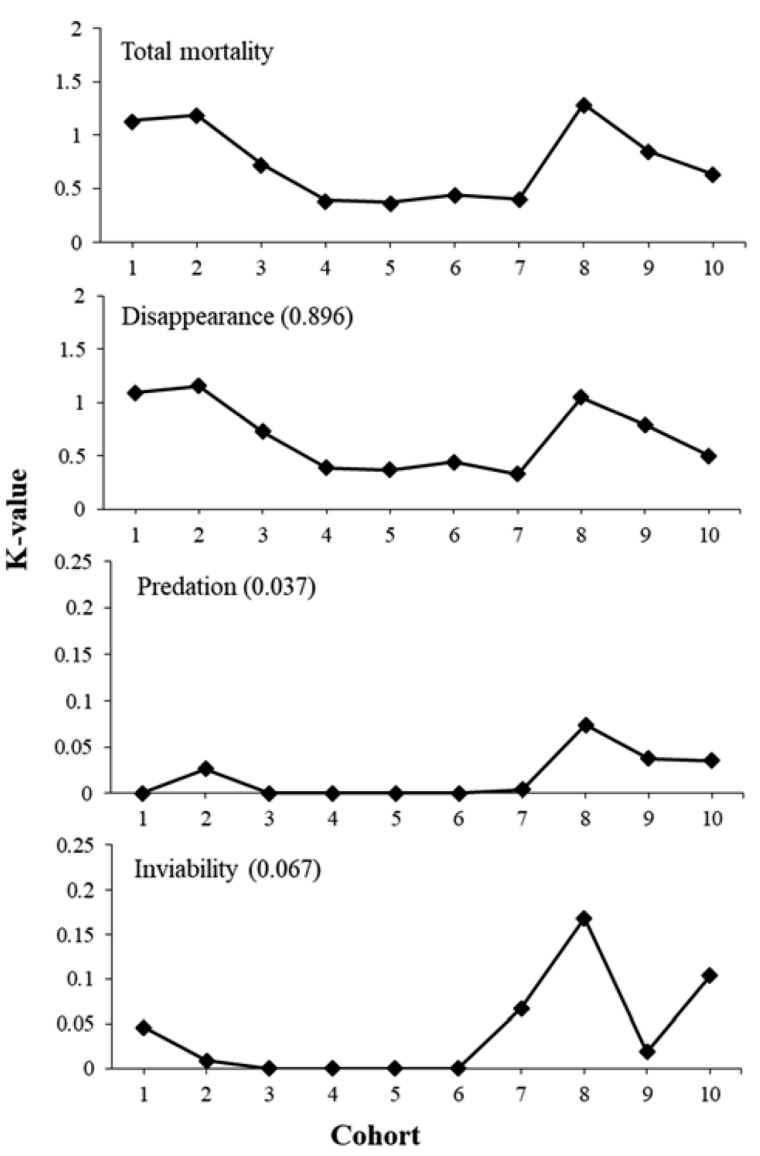

NAROCASS 1
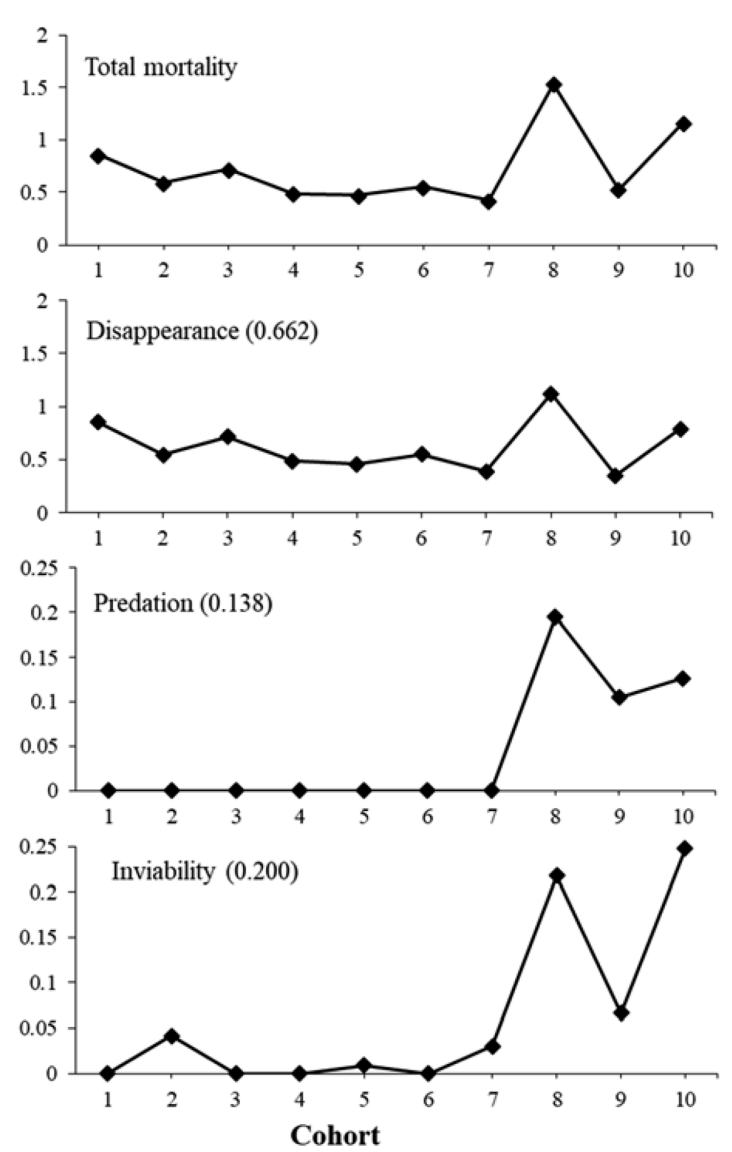

Alado alado

Fig. 4. Key factor analysis for $B$. tabaci SSA1 species egg populations on two cassava genotypes over 10 cohorts in the field. The pattern displayed by total mortality is compared to those of specific causes of death (summed over growth stages). The factor whose graph closely resembles that of total mortality and has the highest slope value (in parenthesis) is the key factor.

had strong effects on parasitism $(r=0.69)$ and unknown death $(r=-0.77)$ while rainfall affected disappearance $(r=$ $-0.56)$ and predation $(r=0.75)$.

In eggs, a strong negative effect of air temperature on disappearance $(r=-0.64)$ and a positive effect of sunshine hours on predation $(r=0.59)$ was observed in 2016. In 2017 , only sunshine hours and wind speed had strong positive effects on disappearance and predation (Table 4).

\section{Key factor analysis}

The comparison of individual k-values of the different mortality factors to total mortality showed that the curve for disappearance was most similar to that of total mortality, and disappearance resulted in the largest regression slope for both eggs and nymphs in both genotypes (Fig. 4 and 5).

\section{DISCUSSION}

This study identified and quantified the impact of different mortality factors acting on immature populations of B. tabaci SSA1 species in a controlled field experiment on cassava. A three-part investigative approach (marginal mortality, irreplaceable and key factor analysis) was used

Table 4. Correlation coefficients ( $r$ ) of mean levels of immature $B$. tabaci SSA1 mortality for each mortality factor with different weather parameters in Wakiso across 10 cohorts on cassava in 2016 and 2017.

\begin{tabular}{|c|c|c|c|c|c|c|c|c|c|c|}
\hline \multirow[b]{2}{*}{$\begin{array}{l}\text { Weather } \\
\text { parameter }\end{array}$} & \multicolumn{5}{|c|}{2016} & \multicolumn{5}{|c|}{2017} \\
\hline & $\begin{array}{c}\text { Air } \\
\text { temperature }\end{array}$ & $\mathrm{RH}$ & Rain fall & $\begin{array}{c}\text { Sunshine } \\
\text { hours }\end{array}$ & $\begin{array}{l}\text { Wind } \\
\text { speed }\end{array}$ & $\begin{array}{c}\text { Air } \\
\text { temperature }\end{array}$ & $\mathrm{RH}$ & Rain fall & $\begin{array}{c}\text { Sunshine } \\
\text { hours }\end{array}$ & $\begin{array}{l}\text { Wind } \\
\text { speed }\end{array}$ \\
\hline \multicolumn{11}{|l|}{ EGGS } \\
\hline Disappearance & -0.64 & 0.48 & 0.37 & 0.45 & -0.10 & 0.46 & -0.23 & -0.25 & 0.56 & 0.99 \\
\hline Inviability & -0.46 & 0.29 & 0.02 & 0.33 & -0.06 & 0.01 & 0.46 & -0.05 & 0.45 & 0.48 \\
\hline Predation & -0.16 & 0.00 & -0.53 & 0.59 & 0.29 & 0.17 & 0.22 & 0.45 & 0.92 & 0.72 \\
\hline \multicolumn{11}{|l|}{ NYMPHS } \\
\hline Disappearance & -0.87 & 0.92 & 0.65 & -0.37 & 0.30 & 0.06 & -0.40 & -0.56 & -0.14 & -0.33 \\
\hline Parasitism & 0.75 & -0.83 & -0.65 & 0.37 & -0.39 & -0.40 & 0.69 & 0.36 & 0.24 & 0.40 \\
\hline Predation & 0.51 & -0.62 & -0.49 & 0.54 & -0.11 & 0.33 & -0.35 & 0.75 & 0.36 & 0.15 \\
\hline Unknown death & 0.77 & -0.74 & -0.51 & 0.77 & 0.70 & 0.50 & -0.77 & -0.36 & -0.21 & -0.67 \\
\hline
\end{tabular}



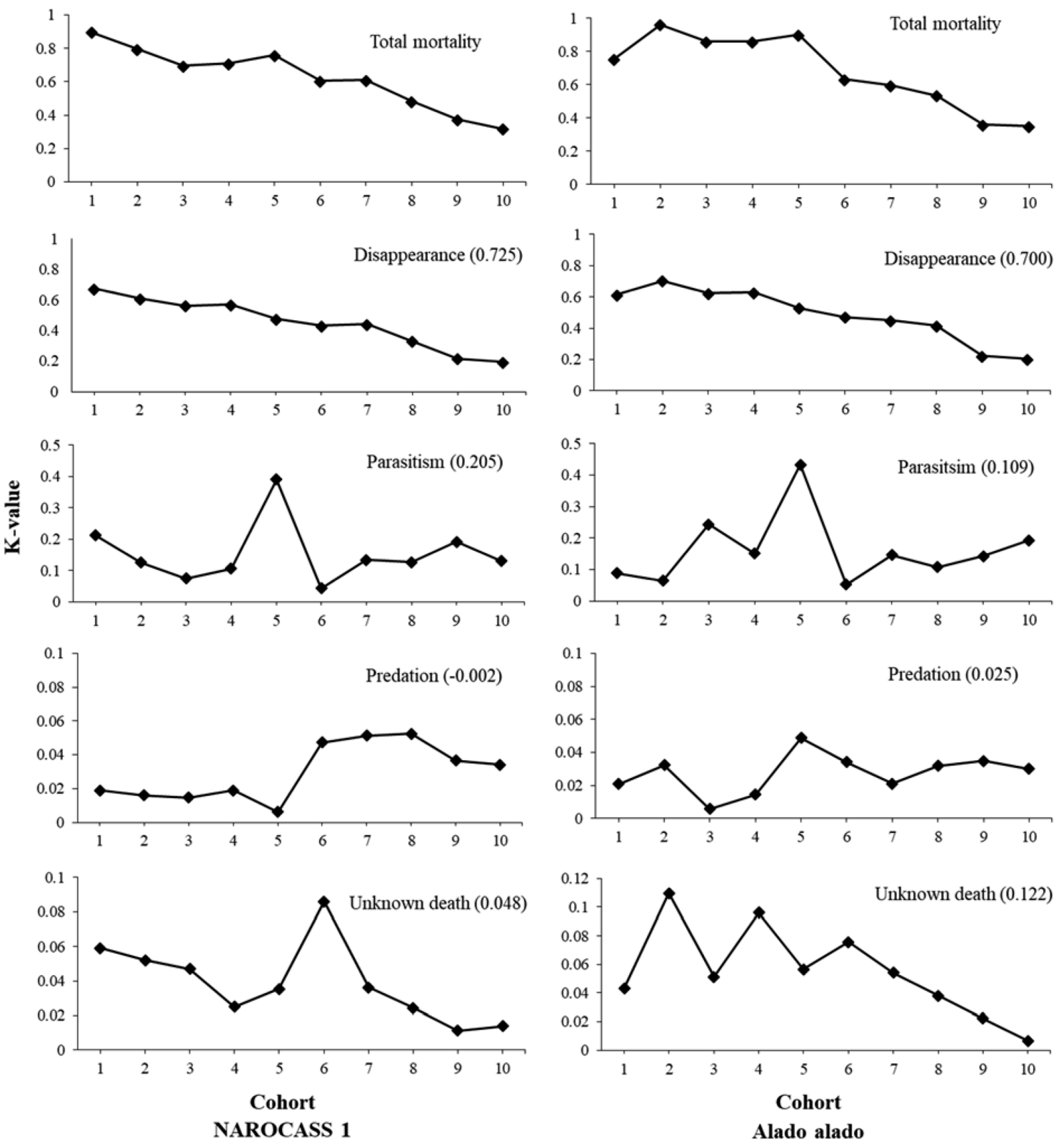

Fig. 5. Key factor analysis for $B$. tabaci SSA1 species nymph populations on two cassava genotypes over 10 cohorts in the field. The factor whose graph closely resembles that of total mortality and has the highest slope value (in parenthesis) is the key factor.

to understand and assess the relative importance of each mortality factor. The cohort-based system, coupled with the daily observations of each individual in the cohort was able to give us comprehensive data on the rates of mortality affecting this pest.

Based on marginal mortality rates and the life table results, disappearance followed by third and fourth instar parasitism were found to be the largest components of overall $B$. tabaci SSA1 species mortality, followed by unknown factors (nymphs only), inviability (eggs only), and predation. The results show that disappearance was the most important factor driving both egg and nymph mortality. Disappearance can be attributed to abiotic factors like wind and rain, and also predators that remove the entire individual from the leaf, like ants and spiders. Parasitism in the third instar was the second factor driving nymph mortality. The high levels of parasitism were attributed to the high numbers of Aphelinidae parasitoids (Eretmocerus mundus Mercet and Encarsia sophia Girault and Dodd), which are abundant in our system (Otim et al., 2005).

The high irreplaceable mortality from disappearance, coupled with its high regression coefficient from key factor analysis points to its importance in reducing both egg and nymph populations of $B$. tabaci SSA1. This result is in agreement with the findings of Horowitz (1984), who reported disappearance as the key mortality factor in $B$. $t a-$ baci in cotton. However, these results are in partial agreement with findings of Asiimwe et al. (2007), who reported that disappearance was the key factor driving egg mortality whereas parasitism in the fourth instar was the key factor driving nymph mortality. In contrast, key factor analysis revealed disappearance followed by third instar parasitism 
as the key mortality factor in our study. The subtle differences between our findings and those of Asiimwe et al. (2007) could be due to differences in cassava genotypes used in each study. Cassava genotype NASE 4 was used by Asiimwe et al. (2007). Furthermore, the identity of whiteflies colonizing cassava during the 2003 study was not known, yet it may be responsible for the observed variations in the key mortality factors reported. Until recently, species diversity among the members of $B$. tabaci has been vague due to inconsistent global phylogenies (Boykin et al., 2007; De Barro et al., 2011), hence the generic use of $B$. tabaci with no concern for the specific species that colonized cassava at that time. However, Bemisia tabaci SSA1 species is currently the most common species colonizing cassava in Uganda (Mugerwa et al., 2012; Legg et al., 2014; Ally et al., 2019) particularly in Wakiso (Kalyebi et al., 2018).

The average monthly air temperature $\left(26-31.5^{\circ} \mathrm{C}\right), \mathrm{RH}$ $(50-75 \%)$, wind speed $(3-5.5 \mathrm{~km} / \mathrm{h})$ and total monthly rainfall $(3-140 \mathrm{~mm}$ ) conditions in the two years of our study were within the optimum range for B. tabaci reproduction and growth. The narrow and consistent range of these parameters could not give conclusive evidence of the impact of weather parameters on B. tabaci mortality. However, it is possible that rainfall indirectly influenced disappearance through its effects on host-plant quality (Guz et al., 2016). Indeed in 2016, where drought conditions were experienced, cassava grew poorly into short plants with small leaves (Katono et al., unpubl.), which increased the exposure of $B$. tabaci individuals to death from wind and rainfall. The high levels of disappearance in both years may highlight the importance of chewing predators and ants and spiders were frequently observed in our trial plots. The positive impact of air temperature on mortality due to natural enemies may be because of their enhanced ability to suppress pest populations under the temperature ranges observed (Huang et al., 2008). Under warmer temperatures, higher parasitoid reproductive success (Zilahibalogh et al., 2009; Romo \& Tylianakis, 2013; Kambrekar et al., 2015) and greater survival of coccinellids (Simmons \& Legaspi, 2004; Huang et al., 2008; Yao et al., 2019) have been reported.

Though we anticipated higher mortality rates on Alado alado, a genotype that supports low field $B$. tabaci adult populations (C.A. Omongo, pers. commun.; Katono et al., unpubl.), there were no significant differences in mortality of $B$. tabaci SSA1 between Alado alado and NAROCASS 1. We used a controlled field experiment and therefore we standardised the numbers of eggs and nymphs entering the data set on each cassava genotype (which is impossible in uncontrolled field surveys and studies). Our findings suggest that genotype differences (if they exist) may only affect B. tabaci adult populations (as reported by Katono et al., unpubl.; Omongo et al., 2012) with no impact on mortality of immature $B$. tabaci SSA1 stages (at least for the two genotypes included here). Similar results were reported on cotton by Karut \& Naranjo (2009). These results suggest the presence of an antixenosis resistance mechanism in
Alado alado. Previous studies also reported high levels of antixenosis resistance to B. tabaci in soybean and Amrasca devastans (Distant) in cotton due to low trichome density (Murugesan \& Kavitha, 2010; da Silva et al., 2012), and $A$. devastans due to high plant height in cotton (Murugesan \& Kavitha, 2010). Legg (1995), reported higher numbers of $B$. tabaci parasitoids in improved cassava genotypes as opposed to the low numbers in local genotypes, however, parasitism rates between different cassava genotypes were similar in uncontrolled field surveys (Macfadyen et al., 2020).

We showed that disappearance is the key mortality factor acting on all the immature stages of $B$. tabaci SSA1 on cassava, followed by third instar parasitism. Previous studies suggest that adding mortality to a factor that is already occurring at high levels has a greater consequence on cohort survival than a diversity of mortality factors (Morris, 1957; Asiimwe et al., 2007; Séverine et al., 2015). Therefore practices which enhance the disappearance and parasitism would offer the most effective way of increasing overall mortality of $B$. tabaci SSA1. There is a range of interventions that may achieve this. Early planting of cassava, at the beginning of the rainy season, would intensify the effect of disappearance on all immature stages of $B$. tabaci, since disappearance is associated with abiotic factors, such as rain and wind (Naranjo \& Ellsworth, 2005). Natural enemy augmentation could also enhance parasitism where low natural enemy populations occur (Perez-Alvarez et al., 2019). Therefore, augmentative release of E. mundus and E. sophia, especially in the second and third instar stage to supplement the naturally occurring parasitoid populations, may help to enhance parasitism.

The greater use of cassava genotypes that are less attractive to adult $B$. tabaci SSA1 such as Alado alado (Katono et al., unpubl.) will reduce the numbers of eggs entering fields planted with such genotypes and assist the mortality agents identified here to reduce $B$. tabaci SSA1 abundance at the field-level. However, for landscape-scale $B$. tabaci population reductions, cassava genotypes that have increased mortality in the immature B. tabaci stages (antibiosis resistance mechanisms) are desperately needed for East African cassava systems. For example, the South American genotype MEcu 72 displays nymphal mortality of $73 \%$ (Bellotti \& Arias, 2001). Our study has shown that for the two cassava genotypes used, there is no increase in mortality of immature stages on Alado alado (the reportedly more tolerant genotype). This means that Alado alado does not have any of the antibiosis mechanisms that would be expected in genotypes displaying host plant resistance, in addition to being susceptible to CBSD and CMD. Breeders should, therefore, focus on developing $B$. tabaci resistant/tolerant cassava genotypes with traits that may increase immature B. tabaci mortality and adult nonpreference. Low leaf area is associated with an increased likelihood of disappearance of eggs and nymphs due to increased exposure (Sippell et al., 1987; Katono et al., unpubl.) while relatively tall plants are not preferred by adults (Murugesan \& Kavitha, 2010; Khalil et al., 2015; Katono 
et al., unpubl.), thus reducing B. tabaci numbers that farmers desire. Since cassava in Uganda is grown under natural conditions, deployment of a pest management strategy for B. tabaci SSA1 which focuses on enhancing the levels of third instar parasitism will provide for more sustainable management of $B$. tabaci SSA1. There is a need to further investigate and understand the possible factors associated with disappearance which can be exploited in the management of B. tabaci.

ACKNOWLEDGEMENTS. We acknowledge the technical and logistical support from the Root Crops Programme at the National Crops Resources Research Institute and Makerere University. Special thanks to E. Kayiwa, J. Kayima, and V. Etumu for fieldwork-based technical support.

FUNDING. This work was supported by the Natural Resources Institute, University of Greenwich from a grant provided by the Bill \& Melinda Gates foundation (Grant Agreement OPP1058938).

\section{DECLARATIONS OF INTEREST. None.}

\section{REFERENCES}

Alicai T., Omongo C.A., Maruthi M.N., Hillocks R.J., Baguma Y., Kawuki R., Bua A., Otim-Nape G. \& Colvin J. 2007: Re-emergence of cassava brown streak disease in Uganda. Plant Dis. 91: 24-29.

Ally H.M., Hamss H.E., Simiand C., Maruthi M.N., Colvin J., Omongo C.A. \& Delatte H. 2019: What has changed in the outbreaking populations of the severe crop pest whitefly species in cassava in two decades? - Sci. Rep. 9: 14796, 14 pp.

Asimme P., EcaAt J.S., Otim M., Gerling D., Kyamanywa S. \& LEGG J.P. 2007: Life-table analysis of mortality factors affecting populations of Bemisia tabaci on cassava in Uganda. Entomol. Exp. Appl. 122: 37-44.

Banjo A.D. 2010: A review of on Aleurodicus dispersus Russel (spiralling whitefly) [Hemiptera: Aleyrodidae] in Nigeria. $-J$. Entomol. Nematol. 2: 1-6.

BASKAUF S.J. 2003: Factors influencing population dynamics of the southwestern corn borer (Lepidoptera: Crambidae): A reassessment. - Environ. Entomol. 32: 915-928.

Bates D., Mächler M., Bolker B. \& Walker S. 2015: Fitting linear mixed-effects models using lme4. - J. Stat Softw. 67(1): $1-48$.

Bellotti A.C. \& Arias B. 2001: Host plant resistance to whiteflies with emphasis on cassava as a case study. - Crop Prot. 20 813-823.

Binu A., Palaniswami M.S. \& Henneberry T.J. 2003: Encarsia transvena (Hymenoptera: Aphelinidae) development on different Bemisia tabaci Gennadius (Homoptera: Aleyrodidae) instars. - Environ. Entomol. 32: 584-591.

Boykin L.M., Shatters R.G., Rosell R.C., Mckenzie C.L., AnN R., De Barro P. \& Frohlich D.R. 2007: Global relationships of Bemisia tabaci (Hemiptera: Aleyrodidae) revealed using Bayesian analysis of mitochondrial COI DNA sequences. Mol. Phylogenet. Evol. 44: 1306-1319.

BuONACCORSI J. \& ElKinTon J.S. 1990: Estimation of contemporaneous mortality factors. - Res. Popul. Ecol. (Kyoto) 32: 151-171.

CAREY J.R. 1989: The multiple decrement life table: a unifying framework for cause-of-death analysis in ecology. - Oecologia 78: $131-137$.
Choudhury R., Rizvi P. \& Ahmad S.K. 2013: Age specific life table of Helicoverpa armigera on Cicer arietinum under natural conditions. - Ann. Plant Prot. Sci. 21: 57-61.

Colvin J., Omongo C.A., Maruthi M.N., Otim-Nape G.W. \& Thresh J.M. 2004: Dual begomovirus infections and high $B e-$ misia tabaci populations: Two factors driving the spread of a cassava mosaic disease pandemic. - Plant Pathol. 53: $577-$ 584.

Da Silva J., Baldin E., de Souza E. \& Lourenção A. 2012: Assessing Bemisia tabaci (Genn.) biotype b resistance in soybean genotypes: antixenosis and antibiosis. - Chil. J. Agric. Res. 72: 516-522.

De Barro P.J., Liu S.S., Boykin L.M. \& Dinsdale A.B. 2011: Bemisia tabaci: a statement of species status. - Annu. Rev. Entomol. 56: 1-19.

Dinsdale A., Cook L., Riginos C., Buckley Y.M. \& De Barro P. 2010: Refined global analysis of Bemisia tabaci (Hemiptera: Sternorrhyncha: Aleyrodoidea: Aleyrodidae) mitochondrial cytochrome oxidase 1 to identify species level genetic boundaries. - Ann. Entomol. Soc. Am. 103: 196-208.

Foltyn S. \& Gerling D. 1985: The parasitoids of the aleyrodid Bemisia tabaci in Israel: development, host preference and discrimination of the aphelinid wasp Eretmocerus mundus. Entomol. Exp. Appl. 38: 255-260.

Gerling D., Alomar O. \& Arno J. 2001: Biological control of Bemisia tabaci using predators and parasitoids. - Crop Prot. 20: 779-799.

Guz N., Atlihan R., Tireng Karut S., KaracaoğLu M., Fidan H., Akbaș B., DeĞIrmenci K., ERdoĞan C., Gurkan M., ZchoriFein E. \& Morin S. 2016: Development and survival of Bemisia tabaci reared on Solanum nigrum under field conditions. — Türk. Entomol. Bült. 6: 193-198.

Horowitz A.R. 1984: Life table analysis of the tobacco whitefly Bemisia tabaci (Gennadius) in cotton fields in Israel. - Acta Oecol. 5: 221-233.

Hu J., Zhang X., Jiang Z., Zhang F., Liu Y. \& Li Z. 2017: New putative cryptic species detection and genetic network analysis of Bemisia tabaci (Hemiptera: Aleyrodidae) in China based on mitochondrial COI sequences. - Mitochondrial DNA (Part A) 29: $474-484$.

Huang Z., Ren S. \& Musa P.D. 2008: Effects of temperature on development, survival, longevity, and fecundity of the Bemisia tabaci Gennadius (Homoptera: Aleyrodidae) predator, Axinoscymnus cardilobus (Coleoptera: Coccinellidae). — Biol. Contr. 46: 209-215.

Jarvis A., Ramirez-Villegas J., CAmpo B.V.H. \& Navarro-RaCINES C. 2012: Is cassava the answer to African climate change adaptation? - Trop. Plant Biol. 5: 9-29.

Jiu M., Hu J., Wang L., Dong J., Song Y. \& Sun H. 2017: Cryptic species identification and composition of Bemisia tabaci (Hemiptera: Aleyrodidae) complex in Henan. - J. Insect Sci. 17: $1-7$.

Kalyebi A., Macfadyen S., Parry H., Tay W.T., De Barro P. \& Colvin J. 2018: African cassava whitefly, Bemisia tabaci, cassava colonization preferences and control implications. PLOS ONE 13: e0204862, 14 pp.

Kambrekar D., Guledgudda S., Katti A. \& Mohankumar 2015: Impact of climate change on insect pests and their natural enemies. - Karnataka J. Agric. Sci. 28: 814-816.

KarUt K. \& NARANJO S.E. 2009: Mortality factors affecting Bemisia tabaci populations on cotton in Turkey. - J. Appl. Entomol. 133: 367-374. 
Kawuki R.S., Kaweesi T., Esuma W., Pariyo A., Kayondo I.S., Ozimati A., Kyaligonza V., Abaca A., Orone J., Tumuhimbise R. ET AL. 2016: Eleven years of breeding efforts to combat cassava brown streak disease. - Breed. Sci. 66: 560-571.

Khalil H., Raza A.B.M., Afzal M., Aqueel M.A., Khalil M.S. \& MANSOOR M.M. 2015: Effects of plant morphology on the incidence of sucking insect pests complex in few genotypes of cotton. - J. Saudi Soc. Agric. Sci. 16: 344-349.

Kuznetsova A., Brockhoff P.B. \& Christensen R.H.B. 2016: $\mathrm{lm}$ erTest: Tests in Linear Mixed Effects Models. R Package Version 2.0-33. URL: https://CRAN.R-project.org/package=lmerTest.

LEGG J.P. 1995: The Ecology of Bemisia tabaci (Gennadius) (Homoptera: Aleyrodidae), Vector of African Cassava Mosaic Geminivirus in Uganda. PhD Thesis, University of Reading, UK, 183 pp.

Legg J.P., Sseruwagi P., Boniface S., Okao-Okuja G., Shirima R., Bigirimana S., Gashaka G., Herrmann H.W., Jeremiah S., OBIERo H. ET AL. 2014a: Spatio-temporal patterns of genetic change amongst populations of cassava Bemisia tabaci whiteflies driving virus pandemics in East and Central Africa. Virus Res. 186: 61-75.

Legg J.P., Shirima R., Tajebe L.S., Guastella D., Boniface S., Jeremiah S., Nsami E., Chikoti P. \& Rapisarda C. 2014b: Biology and management of Bemisia whitefly vectors of cassava virus pandemics in Africa. — Pest Manag. Sci. 70: 1446-1453.

LiU T. \& STANSLY P.A. 1996: Oviposition, development, and survivorship of Encarsia pergandiella (Hymenoptera: Aphelinidae) in four instars of Bemisia argentifolii (Homoptera: Aleyrodidae). - Arthropod Biol. 89: 96-102.

Macfadyen S., Tay W., Hulthen A., Paull C., Kalyebi A., Jacomb F., Parry H., Sseruwagi P., Seguni Z., Omongo C. et AL. 2020: Landscape factors and how they influence whitefly pests in cassava fields across East Africa. - Landsc. Ecol. 36: $45-67$.

Maruthi M.N., Jeremiah S.C., Mohammed I.U. \& LegG J.P. 2017: The role of the whitefly, Bemisia tabaci (Gennadius), and farmer practices in the spread of cassava brown streak ipomoviruses. - J. Phytopathol. 165: 707-717.

MoRRIS R. 1957: The interpretation of mortality data in studies on population dynamics. - Can. Entomol. 89: 49-69.

Mugerwa H., Rey M.E.C., Alicai T., Ateka E., Atuncha H., Ndunguru J. \& Sseruwagi P. 2012: Genetic diversity and geographic distribution of Bemisia tabaci (Gennadius) (Hemiptera: Aleyrodidae) genotypes associated with cassava in East Africa. - Ecol. Evol. 2: 2749-2762.

Murugesan N. \& Kavitha A. 2010: Host plant resistance in cotton accessions to the leafhopper, Amrasca devastans (Distant). - J. Biopestic. 3: 526-533.

NARANJo S.E. 2001: Conservation and evaluation of natural enemies in IPM systems for Bemisia tabaci. - Crop Prot. 20: 835-852.

NARANJo S.E. 2007: Survival and movement of Bemisia tabaci (Homoptera: Aleyrodidae) crawlers on cotton. - Southwest. Entomol. 32: 17-23.

Naranjo S.E. \& Ellsworth P.C. 2005: Mortality dynamics and population regulation in Bemisia tabaci. - Entomol. Exp. Appl. 116: 93-108.

Naranjo S.E. \& Ellsworth P.C. 2017: Methodology for developing life tables for sessile insects in the field using the whitefly, Bemisia tabaci, in cotton as a model system. - J. Vis. Exp. 129: e56150, $12 \mathrm{pp}$.

Nweke F.I., Spencer D.S.C. \& Lynam J.K. 2002: The Cassava Transformation: Africans Best-Kept Secret. Michigan State University Press, East Lansing, 273 pp.
Omongo C.A., Kawuki R., Bellotti A.C., Alicai T., Baguma Y., Maruthi M.N., Bua A. \& Colvin J. 2012: African cassava whitefly, Bemisia tabaci, resistance in African and South American cassava genotypes. - J. Integr. Agric. 11: 327-336.

Otim M., Legg J., Kyamanywa S., Polaszek A. \& Gerling D. 2005: Occurrence and activity of Bemisia tabaci parasitoids on cassava in different agro-ecologies in Uganda. - BioControl 50: $87-95$.

Otim M., Legg J., Kyamanywa S., Polaszek A. \& Gerling D. 2006: Population dynamics of Bemisia tabaci (Homoptera: Aleyrodidae) parasitoids on cassava mosaic disease resistant and susceptible varieties. - BioControl Sci. Technol. 16: 205-214.

Perez-Alvarez R., Brian A.N. \& Poveda K. 2019: Effectiveness of augmentative biological control depends on landscape context. - Sci. Rep. 9: 8664, 15 pp.

Podoler H. \& Rogers D. 1975: A new method for the identification of key factors from life-table data. - J. Anim. Ecol. 44: 85-114.

Polston J.E., Barro D. \& Boykin L.M. 2014: Transmission specificities of plant viruses with the newly identified species of the Bemisia tabaci species complex. - Pest Manag. Sci. 70: $1547-1552$.

Revelle W. 2017: psych: Procedures for Personality and Psychological Research. Northwestern University, Evanston, Illinois, URL: https://CRAN.R-project.org/package=psych Version $=$ 1.7.8

Romo C.M. \& TyLianakis J.M. 2013: Elevated temperature and drought interact to reduce parasitoid effectiveness in suppressing hosts. — PLOS ONE 8: e58136, 9 pp.

Séverine A., Boumezoued A., Hardy H.L. \& El Karoui N. 2015: Cause-of-Death Mortality: What Can Be Learned From Population Dynamics? - HAL Open Access Archive. URL: https:// hal.archives-ouvertes.fr/hal-01157900.

Simmons A.M. \& LegasPi J.C. 2004: Survival and predation of Delphastus catalinae (Coleoptera: Coccinellidae), a predator of whiteflies (Homoptera: Aleyrodidae), after exposure to a range of constant temperatures. - Environ. Entomol. 33: 839-843.

Sippell D.W., Bindra O.S. \& Khalifa H. 1987: Resistance to whitefly (Bemisia tabaci) in cotton (Gossypium hirsutum) in the Sudan. - Crop Prot. 6: 171-178.

Urbaneja A. \& Stansly P.A. 2004: Host suitability of different instars of the whitefly Bemisia tabaci 'biotype Q' for Eretmocerus mundus. - BioControl 49: 153-161.

VARLEY G.C. \& GRADWELl G.R. 1960: Key factors in population studies. - J. Anim. Ecol. 29: 399-401.

Venables W.N. \& Ripley B.D. 2002: Modern Applied Statistics with S. 4th ed. Springer, New York, 495 pp.

YANG N.W., JI L.L., LöVEI G.L. \& WAN F.H. 2012: Shifting preference between oviposition vs. host-feeding under changing host densities in two aphelinid parasitoids. - PLOS ONE 7: e41189, 8 pp.

Yao F.L., Zheng Y., Ding X.L., Zhao J.W., Lu X.S., DesneuX N., He Y.X. \& Weng Q.Y. 2019: Effects of heat shock on survival and predation of an important whitefly predator, Serangium japonicum. - Entomol. Exp. Appl. 167: 476-489.

Zilahi-Balogh G.M.G., Shipp J.L., Cloutier C. \& Brodeur J. 2009: Influence of light intensity, photoperiod, and temperature on the efficacy of two aphelinid parasitoids of the greenhouse whitefly. - Environ. Entomol. 35: 581-589.

Received August 13, 2020; revised and accepted April 12, 2021 Published online June 11, 2021 


\section{SUPPLEMENTARY INFORMATION: Life table of B. tabaci SSA1 immature on two cassava genotypes}

The summary of deaths from all the different causes is presented in Table S1. The highest death rates in both genotypes for all stages of growth were as a result of disappearance followed by third instar parasitism. Death rate due to disappearance ranged from $30 \%$ in the second instar to $44 \%$ in the egg stage and was $14 \%$ for third instar parasitism on Alado alado (Table S2). The highest stage-specific mortality for both genotypes was observed in the third instar stage; 55\% for Alado alado and 49\% for NAROCASS 1 . Only about $12 \%$ of the nymphs survived to adult emergence in both genotypes (Table S3). For both the egg and nymph stages, disappearance was associated with the highest mortality of $73 \%$ and $69 \%$ of nymph deaths in Alado alado and NAROCASS 1, respectively (Table S3).

Table S1. Deaths from five causes of mortality of B. tabaci SSA1 immature field populations on cassava in Uganda in 2016 and 2017 in Wakiso.

\begin{tabular}{|c|c|c|c|c|c|c|c|c|c|}
\hline \multirow[b]{2}{*}{ Genotype } & \multirow{2}{*}{$\begin{array}{c}\text { Stage } \\
\text { of growth } \\
x\end{array}$} & \multirow{2}{*}{$\begin{array}{c}\text { No. } \\
\text { beginning } \\
N_{x}\end{array}$} & \multirow{2}{*}{$\begin{array}{c}\text { No. } \\
\text { healthy }\end{array}$} & \multirow{2}{*}{$\begin{array}{c}\text { Total } \\
\text { death } \\
D_{x}\end{array}$} & \multicolumn{5}{|c|}{ Number of death due to } \\
\hline & & & & & $\begin{array}{c}\text { Inviability } \\
D_{1 x}\end{array}$ & $\begin{array}{c}\text { Predation } \\
D_{2 x}\end{array}$ & $\begin{array}{c}\text { Parasitism } \\
D_{3 x}\end{array}$ & $\begin{array}{c}\text { Disappearance } \\
D_{4 x}\end{array}$ & $\begin{array}{c}\text { Unknown death } \\
D_{5 x}\end{array}$ \\
\hline \multirow{6}{*}{ Alado alado } & Egg & 2855 & 1476 & 1379 & 62 & 52 & - & 1265 & - \\
\hline & $1^{\text {st }}$ instar & 7341 & 4953 & 2388 & - & 98 & - & 2228 & 62 \\
\hline & $2^{\text {nd }}$ instar & 4953 & 3225 & 1728 & - & 146 & - & 1476 & 106 \\
\hline & $3^{\text {rd }}$ instar & 3225 & 1440 & 1785 & - & 54 & 438 & 1183 & 110 \\
\hline & $4^{\text {th }}$ instar & 1440 & 870 & 570 & - & 6 & 30 & 496 & 38 \\
\hline & Adult & 870 & 870 & - & - & - & - & - & - \\
\hline \multirow{6}{*}{ NAROCASS 1} & Egg & 2915 & 1518 & 1397 & 55 & 20 & - & 1322 & - \\
\hline & $1^{\text {st }}$ instar & 7415 & 5454 & 1961 & - & 158 & - & 1726 & 77 \\
\hline & $2^{\text {nd }}$ instar & 5454 & 3540 & 1914 & - & 245 & - & 1525 & 144 \\
\hline & $3^{\text {rd }}$ instar & 3540 & 1787 & 1753 & - & 49 & 418 & 1181 & 105 \\
\hline & $4^{\text {th }}$ instar & 1787 & 960 & 827 & - & 13 & 80 & 714 & 20 \\
\hline & Adult & 960 & 960 & - & - & - & - & - & - \\
\hline
\end{tabular}

Table S2. Cause-specific probability of death from specified mortality factors in the presence of all factors acting on immature stages of B. tabaci SSA1 species.

\begin{tabular}{|c|c|c|c|c|c|c|c|}
\hline \multirow[b]{2}{*}{ Genotype } & \multirow{2}{*}{$\begin{array}{c}\text { Stage } \\
\text { of growth } \\
x\end{array}$} & \multirow{2}{*}{$\begin{array}{l}\text { Probability } \\
\text { of death } \\
\mathrm{aq}_{x}\end{array}$} & \multicolumn{5}{|c|}{ Cause of death } \\
\hline & & & $\begin{array}{c}\text { Inviability } \\
\mathrm{aq}_{1 \mathrm{x}}\end{array}$ & $\begin{array}{c}\text { Predation } \\
\mathrm{aq}_{2 x}\end{array}$ & $\begin{array}{c}\text { Parasitism } \\
\mathrm{aq}_{3 x}\end{array}$ & $\begin{array}{c}\text { Disappearance } \\
\mathrm{aq}_{4 x}\end{array}$ & $\begin{array}{c}\text { Unknown death } \\
\mathrm{aq}_{5 x}\end{array}$ \\
\hline \multirow{5}{*}{ Alado alado } & Egg & 0.4830 & 0.0217 & 0.0182 & - & 0.4431 & - \\
\hline & $1^{\text {st }}$ instar & 0.3253 & - & 0.0133 & - & 0.3035 & 0.0084 \\
\hline & $2^{\text {nd }}$ instar & 0.3489 & - & 0.0295 & - & 0.2980 & 0.0214 \\
\hline & $3^{\text {rd }}$ instar & 0.5535 & - & 0.0167 & 0.1358 & 0.3668 & 0.0341 \\
\hline & $4^{\text {th }}$ instar & 0.3958 & - & 0.0042 & 0.0208 & 0.3444 & 0.0264 \\
\hline \multirow{5}{*}{ NAROCASS 1} & Egg & 0.4792 & 0.0189 & 0.0069 & - & 0.4535 & - \\
\hline & $1^{\text {st }}$ instar & 0.2645 & - & 0.0213 & - & 0.2328 & 0.0104 \\
\hline & $2^{\text {nd }}$ instar & 0.3509 & - & 0.0449 & - & 0.2796 & 0.0264 \\
\hline & $3^{\text {rd }}$ instar & 0.4952 & - & 0.0138 & 0.1181 & 0.3336 & 0.0297 \\
\hline & $4^{\text {th }}$ instar & 0.4628 & - & 0.0073 & 0.0448 & 0.3996 & 0.0112 \\
\hline
\end{tabular}

Table S3. Life table of mortality from specified causes at a given stage of $B$. tabaci SSA1 development.

\begin{tabular}{|c|c|c|c|c|c|c|c|c|c|}
\hline \multirow[b]{2}{*}{ Genotype } & \multirow{2}{*}{$\begin{array}{c}\text { Stage of growth } \\
x\end{array}$} & \multirow{2}{*}{$\begin{array}{l}\text { Probability } \\
\text { of death } \\
\qquad a q_{x}\end{array}$} & \multirow{2}{*}{$\begin{array}{c}\text { Fraction living } \\
\text { at beginning } \\
\text { of stage } \\
\mathrm{al}_{\mathrm{x}}\end{array}$} & \multirow{2}{*}{$\begin{array}{c}\text { Fraction } \\
\text { of all deaths } \\
\operatorname{ad}_{x}\end{array}$} & \multicolumn{5}{|c|}{ Fraction of death due to } \\
\hline & & & & & $\begin{array}{l}\text { Inviability } \\
\operatorname{ad}_{1 \mathrm{x}}\end{array}$ & $\begin{array}{l}\text { Predation } \\
\quad \operatorname{ad}_{2 x}\end{array}$ & $\begin{array}{l}\text { Parasitism } \\
\qquad \operatorname{ad}_{3 \mathrm{x}}\end{array}$ & $\begin{array}{l}\text { Disappearance } \\
\qquad \mathrm{ad}_{4 \mathrm{x}}\end{array}$ & $\begin{array}{l}\text { Unknown death } \\
\operatorname{ad}_{5 x}\end{array}$ \\
\hline \multirow{8}{*}{ Alado alado } & Egg mortality & 0.4830 & 1 & 0.4830 & 0.0217 & 0.0182 & - & 0.4431 & - \\
\hline & Nymph mortality & & & & & & & & \\
\hline & $1^{\text {st }}$ instar & 0.3253 & 1 & 0.3253 & - & 0.0133 & - & 0.3035 & 0.0084 \\
\hline & $2^{\text {nd }}$ instar & 0.3489 & 0.6747 & 0.2354 & - & 0.0199 & - & 0.2011 & 0.0144 \\
\hline & $3^{\text {rd }}$ instar & 0.5535 & 0.4393 & 0.2432 & - & 0.0074 & 0.0597 & 0.1611 & 0.0150 \\
\hline & $4^{\text {th }}$ instar & 0.3958 & 0.1962 & 0.0776 & - & 0.0008 & 0.0041 & 0.0676 & 0.0052 \\
\hline & Adult & - & 0.1185 & & - & - & - & - & - \\
\hline & Total nymph death & & & 0.8815 & - & 0.0414 & 0.0638 & 0.7333 & 0.043 \\
\hline \multirow{8}{*}{ NAROCASS 1} & Egg mortality & 0.4792 & 1 & 0.4792 & 0.0189 & 0.0069 & - & 0.4535 & - \\
\hline & Nymph mortality & & & & & & & & \\
\hline & $1^{\text {st }}$ instar & 0.2645 & 1 & 0.2645 & - & 0.0213 & - & 0.2328 & 0.0104 \\
\hline & $12^{\text {nd }}$ instar & 0.3509 & 0.7355 & 0.2581 & - & 0.0330 & - & 0.2057 & 0.0194 \\
\hline & $3^{\text {rd }}$ instar & 0.4952 & 0.4774 & 0.2364 & - & 0.0066 & 0.0564 & 0.1593 & 0.0142 \\
\hline & $4^{\text {th }}$ instar & 0.4628 & 0.2410 & 0.1115 & - & 0.0018 & 0.0108 & 0.0963 & 0.0027 \\
\hline & Adult & - & 0.1295 & & - & - & - & - & - \\
\hline & Total nymph death & & & 0.8705 & - & 0.0627 & 0.0672 & 0.694 & 0.0467 \\
\hline
\end{tabular}

